\title{
ACTUAL DIRECTIONS OF STATE-OWNED ENTERPRISES COMPETITIVENESS ENSURING
}

\section{Tsalan M. I.}

\section{INTRODUCTION}

Entrepreneurship and its development are at the heart of the economic system of countries, regardless of their development level, except the households that are in the early stages of economic development. Nowadays the entrepreneurship in Ukraine is developing, but its functioning is influenced by negative economic and political factors, which on the one hand significantly impedes its development, while overcoming this influence is a stimulating tool for improving the entrepreneurial environment.

\section{The role of state support in the development of Ukrainian entrepreneurship}

Primarily economic and political factors are the main factors that directly affect entrepreneurship in the country. Economic ones include inflationary fluctuations in the national economy, ineffective tax policies, long-lasting general economic instability in the country as a result of the global financial crisis, the Revolution of Dignity, hostilities in the East, corruption, etc. Political factors include political lobbying, the imperfection and often contradictions of the legislative framework, instability of the government and inefficiency of state policy. The problems that impede entrepreneurship are not only at the level of the country, region, or simply the environment in which business entities operate. Problems also occur at the enterprise level, namely: outdated material and technical base, low level of innovation, lack of skills, inconsistency in the position etc. In order to overcome them and successfully develop entrepreneurial activity in the state and regions, it is necessary to ensure an adequate level of state support, which according to G.M. Skudar should be shown in creating the necessary prerequisites for effective work of enterprises ${ }^{1}$. Relevant actions by the state are urgent: from financial to consulting assistance. In Ukraine, public enterprise policy should be oriented towards raising its role and place in the country's economic system. $\mathrm{N}$. Ignatovych and O. Vetchynov point out that the task of the state is to define

1 Скудар Г.М. Організаційно-економічний механізм управління конкурентоспроможністю підприємства: автореф. дис. ... д.е.н. : 08.02.03. Донецьк, 2000. 40 с. 
the institutional and legal framework of entrepreneurship, to create new regulatory mechanisms that complement the competitive market mechanism, preserving freedom of business activity with focus on satisfying public interests, while preserving the nature environment, aligning it with state priorities $^{2}$.

Within the framework of promoting entrepreneurial development, special attention should be paid to the field of state entrepreneurship. The stateowned entrepreneurship is often seen as the economic activity of state-owned enterprises that create tangible goods and provide the services necessary for the development of the national economy. L.Ye. Furdychko notes that providing the public with public goods is among the goals of state entrepreneurship. Unlike individual goods, the production of which is essentially the prerogative of private business, public goods are of the public interest ${ }^{3}$. State entrepreneurship is an instrument of the state economic policy realization, aimed at the development of the economic potential and the public goals achievement. According to G.Ya. Anilovskaya, social equilibrium achieving is an important factor in the development of state-owned entrepreneurship ${ }^{4}$ (Anilovskaya, 2007).

There are discussions in the scientific community about the feasibility of keeping state-owned enterprises in the future, but at the same time appropriate areas remain where they cannot be fully privatized because of the major state resource in the centre of the industry.

The dynamism of the processes that take place in the modern economy necessitates a rethinking of the different ownership enterprises activities basis. The principles of modern companies work are changing, new socio-economic and organizational-economic relations are emerging at the horizontal level ${ }^{5}$. New trends in the national and international economic environments place new requirements before enterprises of different ownership types, including stateowned ones, for reorientation of activities and a system of measures for timely adaptation to these changes. While private enterprises carry out these activities faster, focusing on their own vision, market research and their own capabilities,

${ }^{2}$ Ігнатович Н., Ветчинов О. Державне регулювання як фактор сучасного розвитку підприємництва: світовий досвід. Вісник Киїського національного університету. 2011. № 124. -125 . С. 52-54.

3 Фурдичко Л. Є. Державне підприємництво та його фінансування в Україні. Репозитарій Національного університету «Львівська політехніка». 2011. URL: http://ena.lp.edu.ua:8080/bitstream/ntb/16713/1/382-656-657.pdf

4 Аніловська Г. Я. Місце та роль державного підприємництва в ринковій трансформації. Науковий вісник Національного лісотехнічного університету України. 2007. URL: http://nltu.edu.ua/nv/Archive/2007/17_1/173_Anilowska_17_1.pdf.

${ }_{5}^{5}$ Кочубей Р.В. Содержание понятия «предпринимательская структура». Маркетинг $i$ менеджмент інноваиій. 2012. № 1. С. 64-68. 
state-owned enterprises are often forced to obey government regulation and expect state support.

State-owned enterprises are run by the public authorities, it creates a foundation for them to protect themselves against particular competitive threats and challenges, but at the same time, the lack of an adequate level of financial security does not reduce the risks and challenges of their operating conditions. It is necessary to note that individual steps have been taken in Ukraine, in particular the Strategy for Improving the Public Sector Economic Entities Activities Efficiency was adopted by the Cabinet of Ministers of Ukraine decree No. 662-r of May 27, 2015. This Strategy provides equal conditions in the market for state and private enterprises activity in order to create competitive conditions for them and to stimulate transparent and efficient work for a positive impact on the national and regional economy and the business environment as a whole.

Forestry is one of the important economic activity areas for Ukraine, namely:

- an important component of national and regional wealth;

- favorable ecological environment for human health and source of raw materials for economic development;

- by-products are valuable both for consumers and for production processes;

Forestry belongs to the primary sector of the economy, but at the same time it is closely linked to the secondary, tertiary and quaternary sectors. Forestry is closely interconnected with:

- industry (manufacture of furniture, medicines, perfumes, equipment etc.);

- construction (construction of buildings);

- wholesale and retail trade (sale of timber and by-products);

- agriculture (beekeeping, grazing);

- provision of services (financial, insurance, transport, educational etc.);

- information technologies (application of innovations in the field of forestry).

The foregoing linkages of forestry with the industries imply the interaction of the economic agents working there. At the same time, forestry is a supplier of raw materials for some industries and a consumer of goods and services produced by others. Forestry activities are mainly carried out by forestry enterprises, which, by virtue of their state ownership and history of development in Ukraine, are characterized by:- low level of development and state support;

- activity in the conditions of economic crisis;

- lack of effective organizational and economic support for their development; 
- outdated principles of conducting business activities that do not take into account the factors of competition and their full participation in market relations.

To ensure the competitive development of forestry in the future, E.M. Libanova's view is important. She believes the forestry sector of Ukraine needs immediate organizational and economic transformations in order to ensure the self-sustainability of the industry, taking into account the interests of territorial communities in the context of modern development of the country ${ }^{6}$.

Forestry activity improvement in the regions of Ukraine should be carried out in a comprehensive and simultaneous way with the reform of the entrepreneurial environment in general, the state enterprise sector in particular, otherwise all measures will be ineffective. It is difficult for forestry to overcome the challenges they face in their activities, only with the help of micro- or mezzanine level tools. Being state-owned, without state funding, they are forced to carry out economic activities in the sphere of risk and to manage the results to ensure forestry activities.

For the future development of forestry activity in the conditions of competition, it is important to coordinate the interaction of components of the organizational and economic mechanism, namely the subjects of implementation and regulation of forestry activity in the region, using the appropriate set of tools and levers.

We believe that the aim of the organizational and economic mechanism of forestry activity development in the region should be - to ensure its competitive development in the region, and the mechanism should be based on a system of principles, which must include:

- continuity of development - work on improving forest management must be continuous;

- systematic - the development of forestry activities is an integral part of the ecological, economic and social system and therefore all steps of development must take into account environmental, economic, social interests and tasks;

- principle of continuous monitoring - provides timely analysis of current forestry activities and taking appropriate measures to correct the situation as needed;

- purposefulness - the application of the mechanism is oriented towards the achievement of the main goal of the regional forestry activity;

${ }^{6}$ Соціально-економічний потенціал сталого розвитку України та ії регіонів / за ред. Е.М. Лібанової, М.А. Хвесик. Київ : ДУ ІЕПСР НАН України, 2014. 775 с. 
- controllability - the use of appropriate levers and tools makes it possible to control the current state of the forest industry in the region, to control the process of its development;

- adaptability - the mechanism should facilitate the development of forestry activities in the conditions of rapid change of their functioning environment;

- constructiveness - organizational and economic mechanism provides strategic orientations for perspective development of forestry activities, means of their achievement to ensure the stability of the system.

\section{Foreign experience of competitive development models}

In order to ensure competitive development, forest managers often seek appropriate solutions in managing the enterprise and take into account the conditions of the region and the state development. For qualitative changes in forestry, the positive experience of foreign experience should be taken into account. Considering the need to increase the attention of forestry enterprises to competitiveness issues, it is first of all advisable to study foreign experience of improving the enterprises competitiveness and to borrow acceptable elements. As B.M. Kurganska rightly points out, in the current conditions enterprises seek ways to survive in a difficult market environment. Due to this, the problem of enterprises competitiveness ensuring and the use of foreign experience on this issue becomes even more important and relevant ${ }^{7}$.

As the problems in the area of forestry personnel in the regions and the fluidity of employees exist, it is advisable to consider the Japanese experience of the competitive position of the enterprise enhancing, based on human factors, diligence of employees of the enterprise and Japanese philosophy. The advantages of the Japanese approach (according to Dr. Furuya Noriya) include a strong sense of belonging to the organization (life-long hiring), a high level of cooperation between employees, a high adaptive potential to a high level of customer requirements, a high level of involvement in work, flexible attitude to work, continuous improvement ${ }^{8}$. In order to implement such an approach in Ukraine and in the regions, there should be motivation (including financial one) for people to work diligently at state-owned enterprises for a long time.

Kaizen's philosophy is important at Japanese enterprises, which envisages continuous improvement for both executives and ordinary employees. Kaizen is a Japanese term meaning "continuous improvement", or "change for

${ }^{7}$ Курганська Б. М. Організаційно-економічні механізми забезпечення конкурентоздатності підприємства (на прикладі швейної промисловості) : дис. ... канд. екон. наук : 08.06.01. Львів, 2002.

${ }^{8}$ Празян М. Фактори підвищення конкурентоспроможності в управлінні виробництвом. Японський досвід. Вісник Київського національного університету. 2011. № 124- 125. С. 46 - 49. 
the better". It is a Japanese philosophy based on the continuous improvement of processes in production, management and business as a whole. Its main components are cost reduction, continuous improvement of work efficiency, rational organization of workplaces, quality control, standardization. This philosophy is based on the principles of teamwork, particularly in small groups, motivation of employees to participate in the development of new ideas, stimulation of creative interest, education of personal discipline.

Kaizen's advantage and difference from western concepts is that it supports continuous improvement of processes, often in small steps, without the need for financial costs, while western countries base the competitive development of the enterprise on the introduction of innovations, i.e. technological improvements, which are more difficult to implement in modern times. The Japanese view is convincing that money infusion into a business will not give effect, if business processes are not optimal ${ }^{8}$.

In the regions of Ukraine, especially at state-owned enterprises, including forestry ones, almost no attention is paid to optimizing activities by constantly improving the organization of staff work, including through motivation for professional growth. In Ukraine, the basis of legal entrepreneurship, effective management, which takes into account the trends, needs and requirements of the modern market, should come to the realization. It is important to remember that in the globalized world, in a context of powerful information support and European integration, it is more profitable to build a business system transparently.

The US model of competitive enterprise development is based on the creation and use of a number of specialized strategic programs to improve the competitiveness of the final product. They are based on the understanding of the importance of the such a program implementation, the development of motivational factors for the production of competitive products and quality control system, minimizing defects in work, cost estimation for improving competitiveness. The control system is important. The main criterion for the effectiveness of the product competitiveness management system in the United States is the degree of satisfaction of customer requests ${ }^{9}$.

Drawing parallels with doing business in Ukrainian realities, it should be noted that in Ukraine insufficient attention is paid to the development of an effective system of incentives for workers and the organization of defect-free work, especially at state-owned enterprises. It is important to keep in mind that the professionalism of the internal work organization at the enterprise should

${ }^{9}$ Дахно, I.І., Бабіч, Г.В., Барановська В.М. та ін. Зовнішньоекономічний менеджмент: Київ: Центр учбової літератури. 2012 URL: http://shron.chtyvo.org.ua/Dakhno_Ivan/ Zovnishnoekonomichnyi_menedzhment.pdf 
increase, especially if the success of the enterprise depends on it, under any circumstances.

The Western European experience of competitiveness ensuring envisages its provision and enhancement at the design stage of activity. The possibility of errors and deviations is minimized when designing a product. This principle in Europe is called "defining errors, causes and remedies analyzing". The cost of eliminating the error is greater when it is determined later. Western European corporations grant the consumer the right to make their claims regarding the competitive parameters of the products used. This encourages firms to improve their production ${ }^{9}$. In European business practice, the concept of multi-sector is widely used to enhance the competitive position of the enterprise, enhance its activity, increase profits through the related services production, and therefore the formation of additional areas minimize risks in the event of the main activity failure.

Based on the analysis of the enterprises competitiveness ensuring experience, it should be noted that its elements are common and therefore can also be applied in the field of forestry at the regional level. Today, the lack of competition in the traditional sense between state forestry enterprises is often one of the reasons for the lack of motivation of the managers to improve their competitive position constantly. The demand for development actualises this issue. The aim to become better, to compete for the improvement of its competitive positions should be at the heart of the economic activity of forestry enterprises and therefore it is best to apply a mixed approach that combines elements of different enterprise competitiveness achieving approaches.

Measures that should be kept in mind by managers in forest industry in order to ensure the competitive enterprise development are the following:

- permanent improvement of activity;

- program approach to development;

- pre-project analysis;

- orientation of development to market needs;

- motivational mechanisms;- defect minimization and control.

Managers in forest industry and in other spheres, should become managers with a new type of thinking about enterprise management and profit, change outdated inefficient management approaches, and actively apply an incentive mechanism to maximize results.

Experience should be gained not only in the organization of internal work of the enterprise, but also in the field of efficient forestry activities. This process has already been partially implemented, in particular the experience of Switzerland, a country where forestry is at a high level. Although the system of ownership and history of the Carpathian and Swiss forests are significantly different, but the natural conditions are close, which allows the Swiss forestry 
methods introduction into the Ukrainian forests, in particular the forests of Transcarpathia. Within the framework of the Agency for Sustainable Development of the Carpathian region "Forza", projects of cooperation between Switzerland and Ukraine are being implemented in the area of close to nature forestry. In Switzerland, it is used in $90 \%$ of the forest area. According to this approach stable, multi-breed, stands are being grown, using selective rather than continuous felling. This approach saves financial resources on reforestation and felling through the use of nature-friendly logging technologies.

In Switzerland's forestry practice, community involvement in forest management is worth of consideration. Most forests are community-owned and forest managers only help to manage them. their activities are largely dependent on community taxes, so they have to prove the effectiveness of their actions in forestry ${ }^{10}$.

The issue of forest ownership changes in Ukraine and the regions is debatable. On the one hand, researchers point out that private ownership can stimulate more efficient forest management, while others consider it as a challenge to transfer forests in Transcarpathia and Ukraine as a whole to other forms of ownership. The distribution of economic and controlling functions may be threatened and the State Forestry Agency will lose control over the activities of forestry enterprises. It may happen that the state will perform economic functions for forest protection and reforestation, and private structures - logging, which is attractive from a commercial point of view. Of course, this issue needs in-depth analysis, but first the economy needs to go through a stage of cleaning up corruption schemes, get out of the shadows and change the mentality of people and their attitude to the forest, changing it from a grueling exploitative to a weakly lean one. In the regions of Ukraine, the territorial community often stands aside from forestry, not always having the will and right to intervene, with the exception of individual civic activists. The tools of their influence are the possibility of appeals to check the legality of actions in the forest area and fixation of forest disturbances. For the development of forestry in the region, a harmonious coexistence of forest areas and people should be ensured, without uncontrolled deforestation, which is immediately reflected in their living conditions. Within the framework of the project of introducing nature-friendly forestry, methods of involving communities in forest management planning were tested. But experts from the Forza project noted that neither the authorities nor the communities themselves are fully prepared for active cooperation in forest management. Indeed, in Ukraine, the population is mostly inert to the problems of the forest, people are

${ }^{10}$ Представники міжурядового проекту FORZA вважають, що Закарпаття не готове до залучення сільських громад до ведення лісового господарства. URL: http://zik.ua/ua/ news/2005/09/16/19312. 
busy solving their own more urgent problems. This issue should be addressed through the educational component - the person first must protect the environment in which he/she lives and be interested in using resources effectively. In foreign countries, young people are widely involved in the conservation of the forest fund and in the awareness of its environmental and economic importance. In particular, in Hungary there is a forest information center, where you can get information about the forest.

Analyzing the experience of Sweden, we can identify the following key points that should be addressed in the forestry of Ukraine, namely:

- the law on forestry adopted in Sweden in 1903 has for a long time been at the heart of the Swedish model of forest management, based on the cultivation of one-year stands and the predominance of logging. Due to the fact that this law ceased to be in line with the new vision of future forestry development, in 1993 a new law on forestry was adopted, which took into account changes in the country's forestry policy, namely the emphasis on biodiversity and forest legislation. The priorities were the integration of an approach to environmental protection and the production of quality wood (ecological and economic function) with a predominant selective type of felling. In other words, forest policy, if inconsistent with the realities of the present, can and should be changed, but at the same time should be thoughtful, consistent, and take into account the requirements of the present;

- there is an active cooperation of various branches of government with forestry institutions in Sweden;

- the use of modern equipment in the work of forestry enterprises. Wood is cut according to its quality and plans for further processing using computer technology. X-ray scanners and tomographs are widely used to determine the quality of wood. Much has to be done in Ukraine. The innovation and technological update, as already mentioned, is at a low level, which hinders the development of forestry activities on the basis of competitiveness. An important step forward would be the widespread adoption of drones in the work of foresters for inspection of large areas, monitoring of damaged timber, which would save time and costs for forest area research;

- effectively established cooperative links between forestry and logging enterprises. Much of the physical labor is freed and refocused on controlling and managerial functions. In Sweden, the work of robots has been used in the forestry process for a long time;

- optimized processes of use of wood and waste after its processing. To heat the living quarters, the bark is burned after the process of frying;

- forest policy in Sweden is based on freedom and responsibility, the value of forests is increasing in the long run, and a long-term forest management plan (approximately 20 years) is being developed accordingly; 
- forest ownership in Sweden is divided between individuals (50\%) and companies $(25 \%)$, the state and the church $(25 \%)$, but this does not affect the efficiency of forestry management, as forest law is one for all;

- balance between rational forest management (timber harvesting and processing as an economic function) and conservation of forest resources (in terms of environmental function) ${ }^{11}$.

Having analyzed the experience of Poland, we believe that some elements may be useful for application in Ukraine, in particular, the burden of taxation. The basis of taxation is the area of forest in use, which is an incentive to improve the efficiency of forestry and harvest the maximum volume of timber. In this case, the sense of concealing the results of entrepreneurial activity is lost. As the forest tax in Poland is local, the state thus supports the forest community and promotes efficient forest management.

The experience of Germany is interesting in terms of forestry management. Forest and timber play an important role in the structure of the German economy, with 1.2 million jobs and an annual turnover of 170 billion euros. In Germany, the concept of "efficient and economical" forestry has justified itself. Nowadays, forest in Germany is used as a source of timber, with particular attention being paid to its origin from ecological territory. In Germany, a high-level certification system is developed. The presence of the certificate is a proof of the environmental conditions of the wood origin. Germany states that all timber used by state-owned enterprises must come from eco-friendly territories, from forests that have PEFC (The Programme for the Endorsement of Forest Certification) or FSC (Forest Stewartship Council) certification. An element of German forestry experience is the use of GPS satellite navigation, which enables quick orientation and accurate finding of harvested timber in the forest. With the help of modern computer software, it is possible to monitor the state of forest resources. In their work, forestry workers make extensive use of mobile stations to store information about the species composition of a particular forest area, the volumes and types of logging, and so on.

Summarizing the foreign experience of forestry management, the subjects of forestry activity in Ukraine should take into account:

- orientation towards nature-close forestry;

- compliance of forest management measures with modern tendencies of forestry development in terms of balance of ecological-economic function and social progress;- strengthening of interaction between foresters, authorities and community, involvement of young people in improving forestry, strengthening information, communication and educational functions of management;

11 Швецька модель лісоуправління. URL: https://www.youtube.com/watch?v= 
- long-term planning of forestry activities and efficiency of its organization in terms of innovative technical and technological support.

Considering the potential use of wood (as raw material) in national energy, medicine, production of construction materials, toys, etc., some efforts should be directed to the development of forestry with by-products, which requires its processing in the region, has economic and social impact. The processing of by-products in the region can be carried out independently by individual enterprises, in another way the creation of cluster structures is possible, which combine wood and by-products processing.

An important component of improving the organizational and economic mechanism for the development of forestry in the region is the approximation of the local population to the issues of forestry development.

In this case, it should be ensured:

- regularly informing the local population about the results of forestry management through online resources. Residents of the region should see the results of efficient management, the volume of harvesting and reforestation work, the amount of payments to the budget, the profits and investments in forestry, as well as the problems in the region in this area, measures taken to solve them. This will increase public confidence in the industry and the effectiveness of their management practices;

- joint activities of local people, representatives of forestry and regional authorities on clearing individual forest areas;

- participation of competent citizens in decision-making in the forestry sector, which will facilitate the transparency of the process and make it impossible to approve inefficient decisions;

- to implement on a proper basis public control over forest management;

- to step up youth education and awareness-raising activities regarding the caring of the forest as a place for recreation and leisure. To this end, we support the initiative to promote school forestry, joint actions of forestry workers with schoolchildren to plant forests.

For competitively oriented forestry enterprises, an appropriate infrastructure should exist in the regions, i.e a system of state and nongovernmental structures that will facilitate the rapid adaptation of forestry entities to competitive market conditions. Such infrastructure should address the lack of relevant knowledge, skills and experience of competitiveness. These can be support funds, information and consulting centers, consulting firms. Lack of information on new developments in the field of forestry can be solved by stimulating the exchange of experience between business leaders, lower-level employees, publishing articles, round tables holding, thematic seminars etc.

In order to achieve forestry enterprises competitiveness, state aid is needed as one of the tools for stimulating economic activity in order to achieve 
economic, social and political goals in the domestic and foreign markets ${ }^{12}$. State aid should motivate business entities to work effectively for profit. State aid can be manifested in the form of tax benefits, compensation from state aid providers, which may be central and local executive authorities, local governments.

It is important to introduce a market-based forestry management system in accordance with the declared decentralization trends. The issue of a clear division of forest management is discussed. Today, it is advisable to expand the powers of regional authorities in regulating and facilitating forestry in the region, particularly in the forestry enterprises financing. But, in addition to the positive effects of the reallocation of powers, decentralization reform contains challenges at the initial stage of its implementation, namely:

- the need for legislative consolidation of the powers of the united territorial communities for decision-making in the field of forestry;

- gaining relevant experience;

- search for ways of financial and material support of forestry needs;

- mechanisms for exercising this kind of authority.

The focus of management shifting to the regional level in combination with other measures to improve forestry would increase interest in its effectiveness. In order to intensify the cooperation of forestry entities with local executive authorities, local self-government bodies, it is necessary to hold frequent meetings to discuss urgent problems and issues of further development.

The creation of a forestry cluster and expansion of program approaches to development that take into account regional peculiarities and needs is particularly important direction of activation of the forestry activity development mechanism in the region.

\section{CONCLUSIONS}

In Ukraine, the development of forestry activities should be carried out in the context of effective reforms of the business sector as a whole and of stateowned enterprises in particular, since only in a stable and economic environment created by the state the effectiveness of the implemented measures can be expected.

In order to ensure the development of forestry activities with the aim to achieve a higher level of competitiveness, forestry activities should be undertaken both at the enterprise level and at the regional level. To achieve the same goal, it is advisable to borrow elements of foreign experience. To ensure

${ }^{12}$ Концепція реформування системи державної допомоги суб'єктам господарювання. Схвалено розпорядженням Кабінету Міністрів України від 13 січня 2010 р. № 81-p. URL: http://zakon.nau.ua/doc/?uid=1095.5925.0 
the competitiveness of forestry enterprises, it is necessary to consolidate the focus on continuous improvement of their activities, program development approach, application of pre-project analysis and consideration of market requirements, apply motivational mechanisms in work, focus on minimization of defects and activation of control measures. Considering the foreign experience in forest management, it is necessary to take into account the compliance of forest management measures with the modern requirements of forestry development, taking into account ecological and economic equilibrium and social development goals, orientation to nature-friendly forestry, mutual approximation of forest authorities, community authorities, orientation on innovation and technological renewal of forestry.

\section{SUMMARY}

The role of state support in the development of entrepreneurship in Ukraine has been analyzed by the author. The state-owned entrepreneurship is a tool for the implementation of state economic policy, strengthens its economic potential and contributes to the fulfillment of social goals and their achievement. The individual state-owned enterprises are strategically important for the future development of the state and their transformation into private property can pose a threat to the economic security of the country. The need to implement the foundations of competitive development in such enterprises has also been considered by the author. The foreign experience of enterprises competitiveness improving and the possibility of its use in Ukraine have been considered. Applying the elements of foreign experience can be successful along with activities undertaken by businesses, authorities, relevant management institutions and the local community. The creation of cluster structures is one of the promising directions of increasing the competitiveness of state-owned enterprises.

\section{REFERENCES}

1. Скудар Г.М. Організаційно-економічний механізм управління конкурентоспроможністю підприємства: автореф. дис. ... д.е.н. : 08.02.03. Донецьк, 2000. 40 с.

2. Ігнатович Н., Ветчинов О. Державне регулювання як фактор сучасного розвитку підприємництва: світовий досвід. Вісник Київського національного університету. 2011. № 124. -125. С. 52 - 54.

3. Фурдичко Л. Є. Державне підприємництво та його фінансування в Україні. Репозитарій Національного університету «Львівська політехніка». 2011. URL: http://ena.lp.edu.ua:8080/bitstream/ntb/16713/1/ 382-656-657.pdf. 
4. Аніловська Г. Я. Місце та роль державного підприємництва в ринковій трансформації. Науковий вісник Національного лісотехнічного університету України. 2007. URL: http://nltu.edu.ua/nv/Archive/2007/17_1/ 173_Anilowska_17_1.pdf.

5. Кочубей Р.В. Содержание понятия «предпринимательская структура». Маркетинг і менеджмент інноващій. 2012. № 1. С. 64-68.

6. Соціально-економічний потенціал сталого розвитку України та їі регіонів / за ред. Е.М. Лібанової, М.А. Хвесик. Київ : ДУ ІЕПСР НАН України, 2014. $775 \mathrm{c.}$

7. Курганська Б. М. Організаційно-економічні механізми забезпечення конкурентоздатності підприємства (на прикладі швейної промисловості) : дис. ... канд. екон. наук : 08.06.01. Львів, 2002.

8. Празян М. Фактори підвищення конкурентоспроможності в управлінні виробництвом. Японський досвід. Вісник Київського нащіонального університету. 2011. № 124-125. С. 46-49.

9. Дахно, I.I., Бабіч, Г.В., Барановська В.М. та ін. Зовнішньоекономічний менеджмент: Київ: Центр учбової літератури. 2012 URL: http://shron.chtyvo.org.ua/Dakhno_Ivan/Zovnishnoekonomichnyi_menedzhment.pdf

10. Представники міжурядового проекту FORZA вважають, що Закарпаття не готове до залучення сільських громад до ведення лісового господарства. URL: http://zik.ua/ua/news/2005/09/16/19312.

11. Швецька модель лісоуправління. URL: https://www.youtube.com/ watch? $\mathrm{v}=\mathrm{d} 0 \mathrm{HwOAcjcQE}$.

12. Концепція реформування системи державної допомоги суб'єктам господарювання. Схвалено розпорядженням Кабінету Міністрів України від 13 січня 2010 р. № 81-p. URL: http://zakon.nau.ua/doc/ ?uid=1095.5925.0

\section{Information about the author:} Tsalan M. I., Candidate of Economic Sciences, Associate Professor, Uzhhorod National University 14, Universytetska str, Uzhhorod, 88000, Ukraine 